\title{
Two-pore domain potassium channels in the adrenal cortex
}

\author{
Sascha Bandulik • Philipp Tauber • Enzo Lalli • \\ Jacques Barhanin • Richard Warth
}

Received: 5 September 2014 / Revised: 2 October 2014 / Accepted: 3 October 2014 / Published online: 23 October 2014

(C) The Author(s) 2014. This article is published with open access at Springerlink.com

\begin{abstract}
The physiological control of steroid hormone secretion from the adrenal cortex depends on the function of potassium channels. The "two-pore domain $\mathrm{K}^{+}$channels" (K2P) TWIK-related acid sensitive $\mathrm{K}^{+}$channel 1 (TASK1), TASK3, and TWIK-related $\mathrm{K}^{+}$channel 1 (TREK1) are strongly expressed in adrenocortical cells. They confer a background $\mathrm{K}^{+}$conductance to these cells which is important for the $\mathrm{K}^{+}$ sensitivity as well as for angiotensin II and adrenocorticotropic hormone-dependent stimulation of aldosterone and cortisol synthesis. Mice with single deletions of the Task1 or Task3 gene as well as Task1/Task3 double knockout mice display partially autonomous aldosterone synthesis. It appears that TASK1 and TASK3 serve different functions: TASK1 affects cell differentiation and prevents expression of aldosterone synthase in the zona fasciculata, while TASK3 controls aldosterone secretion in glomerulosa cells. TREK1 is involved in the regulation of cortisol secretion in fasciculata cells. These data suggest that a disturbed function of K2P channels could contribute to adrenocortical pathologies in humans.
\end{abstract}

S. Bandulik $(\bowtie) \cdot$ P. Tauber $\cdot$ R. Warth

Medical Cell Biology, University of Regensburg,

Universitaetsstrasse 31, 93053 Regensburg, Germany

e-mail: sascha.bandulik@ur.de

E. Lalli

Institut de Pharmacologie Moléculaire et Cellulaire, CNRS, Université de Nice Sophia Antipolis, 660 Route des Lucioles, 06560 Valbonne, France

J. Barhanin

LP2M-CNRS-UNS UMR 7370, Faculté de Médecine, Université de Nice Sophia Antipolis, 28 Avenue de Valombrose, 06107 Nice Cedex 2, France

J. Barhanin

Laboratories of Excellence, Ion Channel Science and Therapeutics,

Nizza, France
Keywords KCNK2 $\cdot \mathrm{KCNK} 3 \cdot \mathrm{KCNK} 9 \cdot \mathrm{TASK} \cdot \mathrm{TREK} \cdot$ Aldosterone

\section{Introduction}

The distinct zones of the adrenal cortex produce different steroid hormones, which regulate several important physiological functions. The mineralocorticoid aldosterone is synthesized by the outermost cell layer (zona glomerulosa) beneath the capsule of the adrenal gland. Glucocorticoids are produced in the zona fasciculata that consists of column-like organized cells below zona glomerulosa. In humans, but not in rodents, the innermost zona reticularis cells produce androgenic steroid hormones. In cells of all three zones of the adrenal cortex, the function of $\mathrm{K}^{+}$channels is an important determinant for controlling hormone secretion, cell differentiation, proliferation, and possibly apoptosis. This review aims to discuss the physiology and pathophysiology of "two-pore domain $\mathrm{K}^{+}$channels" (K2P) in the adrenal cortex, especially in aldosterone-producing glomerulosa cells.

Aldosterone controls the extracellular fluid and salt balance by stimulation of sodium reabsorption and potassium secretion in the distal nephron of the kidney, in the distal colon, and in sweat glands. By controlling water and salt balance and by direct effects on the cardiovascular system, aldosterone has a major impact on blood pressure control. So-called primary aldosteronism is characterized by inappropriately high plasma aldosterone levels due to autonomous aldosterone synthesis. Inadequately high aldosterone secretion is believed to be causal for about $3 \%$ of the cases of arterial hypertension [97]. Additionally, aldosterone contributes to cardiac fibrosis, cardiovascular dysfunction, and progressive kidney disease $[59,111]$. The relevance of aldosterone as clinical risk factor has been stressed by clinical trials (Aldosterone Evaluation Study (RALES); EPlerenone HEart failure and SUrvival 
Study (EPHESUS)) [16, 148]. Therefore, understanding the physiology and pathophysiology of aldosterone synthesis is of great relevance for the diagnosis and treatment of arterial hypertension and cardiovascular disease.

It is known for a long time that the regulation of aldosterone synthesis strongly depends on the modulation of the membrane potential of glomerulosa cells. Also cortisol synthesis appears to be stimulated by depolarization of the plasma membrane. The membrane potential of resting adrenocortical cells is mainly determined by the function of $\mathrm{K}^{+}$channels. Accordingly, the disturbed function of adrenal $\mathrm{K}^{+}$channels has pathological consequences for the regulation of steroid hormone production, and it may lead to excessive proliferation of adrenocortical cells.

\section{Adrenocortical $\mathrm{K}^{+}$channels}

The resting membrane potential of human glomerulosa cells is set by a number of $\mathrm{K}^{+}$channels, particularly of the K2P family, which are highly expressed among species (Table 1). In rodents, two members of the TWIK-related acid sensitive $\mathrm{K}^{+}$(Task) family (Task1 and Task3) were shown to play an important role in the regulation of aldosterone secretion and adrenocortical cell differentiation [7, 28, 34, 51, 55, 103]. TWIK-related $\mathrm{K}^{+}$channel 1 (Trek1) is important for the normal function of the bovine adrenal cortex [38, 41]. The role of $\mathrm{K} 2 \mathrm{P}$ channels in the human adrenal gland is still under investigation. Several studies indicate that K2P channels contribute to the physiological control of aldosterone synthesis in human adrenocortical cells. TASK1 is strongly expressed in the human adrenal cortex [22] and in the human adrenocortical NCI-H295R cell line [96]. Silencing of TASK1 expression stimulates aldosterone secretion in NCIH295R cells [96]. TREK1 and TASK3 $\mathrm{K}^{+}$channels are also expressed in NCI-H295R cells, albeit on a much lower level than TASK1 [96]. Inactivation of TREK1 and TASK 3 depolarizes the membrane potential of NCI-H295R cells. However, the amount of this depolarization is likely small, because aldosterone production is not significantly increased [14]. Decreased expression of TASK2 was found in adrenal adenomas [5, 72], and suppression of TASK2 activity in NCI-H295R cells increased aldosterone synthesis [72]. TREK1 was shown to dominate the $\mathrm{K}^{+}$conductance of human fasciculata cells [39]. Most of the knowledge about the functional role of Task $\mathrm{K}^{+}$channels has been obtained by phenotyping different knockout mouse models. The following paragraphs aim at providing a comprehensive overview of the specific role and relevance of K2P channels for the regulation of steroid hormone synthesis and zonal differentiation of the adrenal gland.

\section{Stimulation of aldosterone secretion}

Aldosterone synthesis in adrenal zona glomerulosa cells is mainly stimulated by angiotensin II (Ang-II), by high plasma $\mathrm{K}^{+}$concentrations, and, to a minor extent, by the adrenocorticotropic hormone (ACTH). For the stimulation of aldosterone synthesis by Ang-II or hyperkalemia, modulation of the membrane potential is an early and critical early event in the cellular signaling cascade (Fig. 1). Therefore, precise control of the membrane voltage is very important. A large proportion of the $\mathrm{K}^{+}$channels that determine the resting membrane voltage of glomerulosa cells are constitutively open, e.g., "background" or "leak" $\mathrm{K}^{+}$channels of the K2P family. Due to the high $\mathrm{K}^{+}$conductance, the resting membrane potential of glomerulosa cells is hyperpolarized $(-80 \mathrm{mV})$, close to the $\mathrm{K}^{+}$ equilibrium potential. An increase of the extracellular $\mathrm{K}^{+}$ concentration, according to Nernst's equation, leads to a positive shift of the $\mathrm{K}^{+}$equilibrium potential and to a depolarization. By this mechanism, glomerulosa cells are able to sense changes of plasma $\mathrm{K}^{+}$concentration, reminiscent of $\mathrm{K}^{+}$-selective electrodes. Upon depolarization of the membrane, voltage-dependent T-type and L-type $\mathrm{Ca}^{2+}$ channels are activated, thereby translating the membrane depolarization into a rise of the intracellular $\mathrm{Ca}^{2+}$ activity. High intracellular $\mathrm{Ca}^{2+}$ activity, via binding to calmodulin and activation of calmodulin-dependent kinases, induces transcription of particular enzymes needed for aldosterone synthesis, e.g., aldosterone synthase (CYP11B2), and steroidogenic acute regulatory protein (StAR) [23]. Aldosterone synthase catalyzes the final three-step reaction from 11-deoxycorticosterone to aldosterone, and it is considered to be the rate-limiting enzyme of aldosterone synthesis. StAR is a transport protein facilitating the shuttling of cholesterol from the outer to the inner mitochondrial membrane where cholesterol is converted to pregnenolone, a precursor of steroid hormones.

The mechanism by which Ang-II depolarizes the membrane is different from the one of high extracellular $\mathrm{K}^{+}$. Ang-II depolarizes the plasma membrane by inhibiting background $\mathrm{K} 2 \mathrm{P} \mathrm{K}^{+}$channels. The molecular mechanism of the Ang-II-mediated $\mathrm{K}^{+}$channel inhibition was a matter of debate for a long time $[19,79,87,121]$ but was solved only recently. Binding of Ang-II to the $\mathrm{AT}_{1}$ receptor activates phospholipase- $C$ via $G_{\alpha q}$-proteins. By cleavage of phosphatidylinositol 4,5-bisphosphate $\left(\mathrm{PIP}_{2}\right)$, phospholipase-C generates diacylglycerol (DAG) and inositol-triphosphate $\left(\mathrm{IP}_{3}\right)$. Interestingly, it appears that DAG acts as a K2P channel-inhibiting factor leading to a strong decrease of the fractional $\mathrm{K}^{+}$conductance and depolarization of the membrane [145]. Similar to the high $\mathrm{K}^{+}$-induced depolarization, the Ang-II-induced depolarization activates voltage-gated $\mathrm{Ca}^{2+}$ channels and leads to $\mathrm{Ca}^{2+}$ influx $[1,58,137]$. In addition, Ang-II facilitates the opening of $\mathrm{Ca}^{2+}$ channels by lowering the voltage threshold for activation [84], and it induces a 


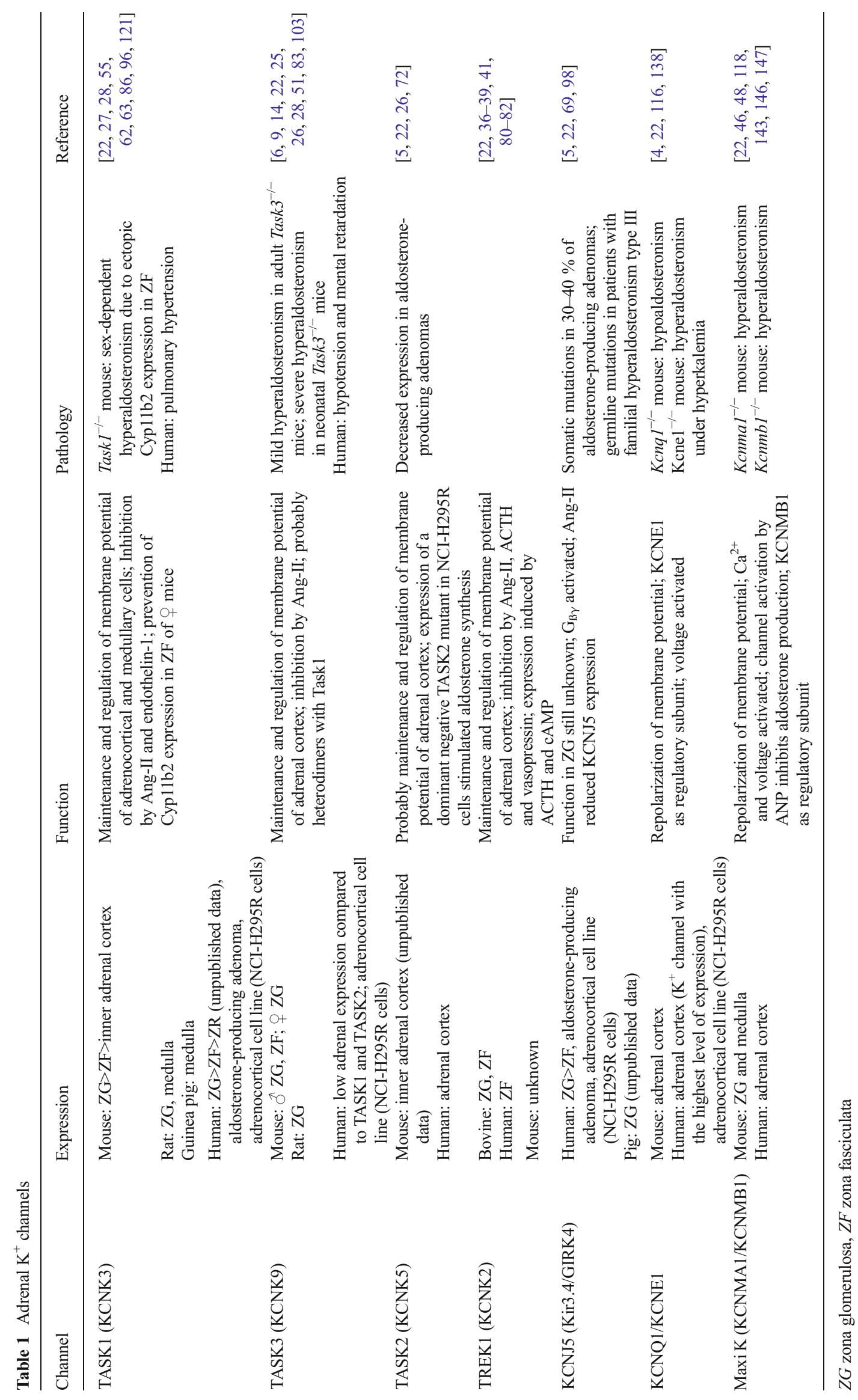



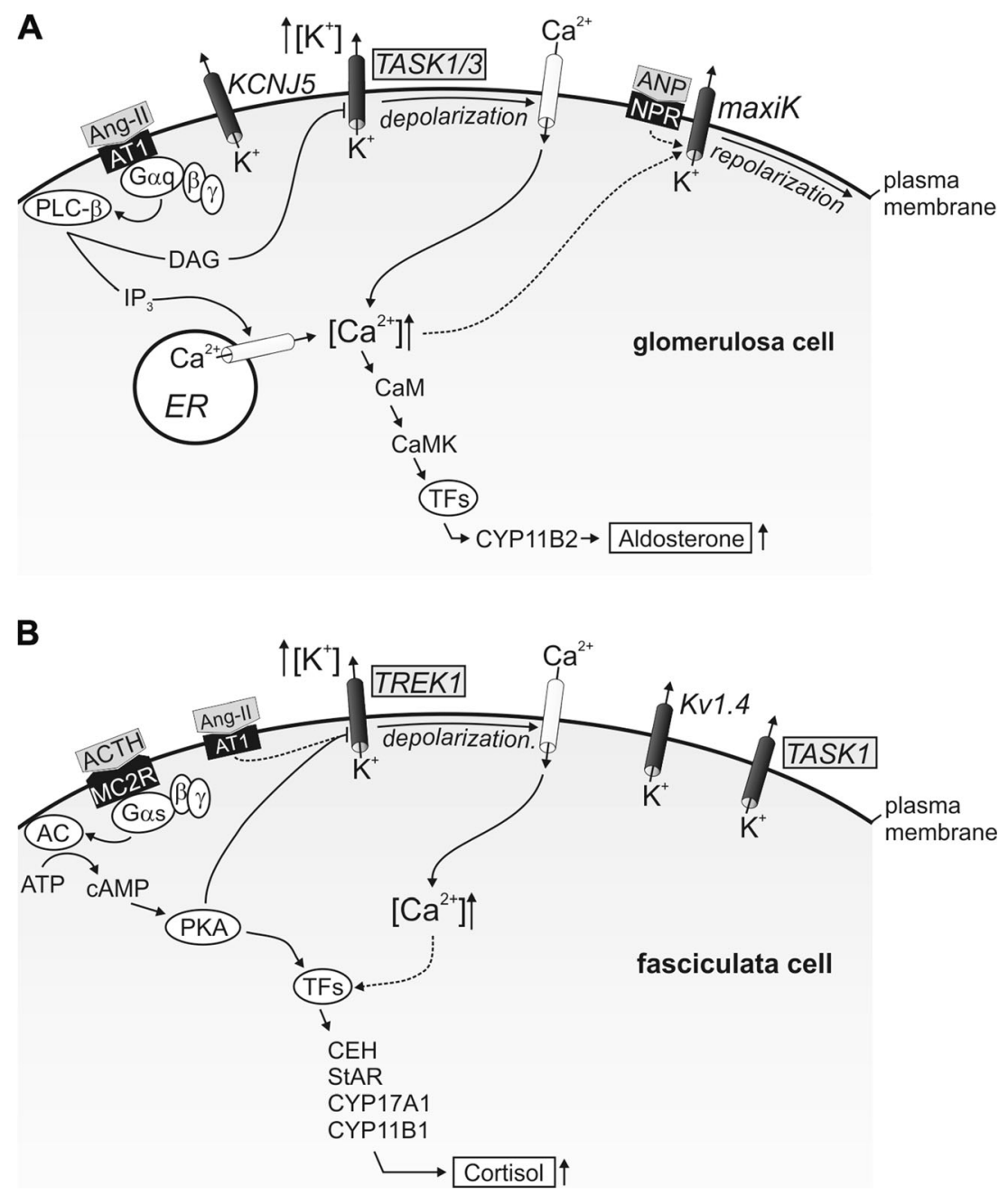

Fig. 1 Simplified models for the regulation of aldosterone synthesis in zona glomerulosa cells (a) and of cortisol synthesis in zona fasciculata cells (b). a Stimulatory action of Ang-II and increased plasma $\mathrm{K}^{+}$concentration on aldosterone synthesis depends on membrane voltage depolarization and on increased cytosolic $\mathrm{Ca}^{2+}$. G-Protein-dependent activation of phospholipase-C (PLC- $\beta$ ) via binding of Ang-II to angiotensin receptor 1 (AT1) leads to generation of inositol-triphosphate $\left(\mathrm{IP}_{3}\right)$ and diacylglycerol (DAG). $\mathrm{IP}_{3}$ stimulates $\mathrm{Ca}^{2+}$ store release from the endoplasmatic reticulum (ER). DAG-dependent inhibition of TASK1 and TASK $3 \mathrm{~K}^{+}$channels or a high $\mathrm{K}^{+}$-induced shift of the Nernst potential depolarize the membrane. The depolarization activates voltage-dependent $\mathrm{Ca}^{2+}$ channels. $\mathrm{Ca}^{2+}$-calmodulin activates CaM-Kinases, and this leads to activation of transcription factors (TFs) and increased transcription of CYP11B2 (aldosterone synthase). MaxiK $\mathrm{K}^{+}$channels are activated by the atrial natriuretic peptide (ANP), which binds to the natriuretic peptide receptor (NPR), or by increases of cytosolic $\mathrm{Ca}^{2+}$.
MaxiK channels repolarize glomerulosa cells and decrease aldosterone synthesis. KCNJ5 $\mathrm{K}^{+}$channels are highly expressed in human glomerulosa cells, but seem to be inactive under control conditions. b The stimulatory effect of ACTH on cortisol synthesis depends on cAMPdependent signaling, but also involves membrane depolarization and increased cytosolic $\mathrm{Ca}^{2+}$. ACTH binds to the melanocortic-2-receptor $(\mathrm{MC} 2 \mathrm{R})$ and leads to activation of $\mathrm{G}_{\alpha \mathrm{s}}$-protein that stimulates adenylate cyclase (AC). cAMP-activated protein kinase A (PKA) activates transcription factors (TFs) inducing transcription of steroidogenic enzymes. These enzymes are required for cortisol synthesis (e.g., CHE: cholesterolester hydrolase, StAR: steroidogenic acute regulated protein, CYP17A1, CYP11B1). PKA also inhibits TREK1 $\mathrm{K}^{+}$channels, depolarizes the membrane and promotes $\mathrm{Ca}^{2+}$ influx and consecutive activation of transcription factors. TREK1 is also inhibited by Ang-II. Additionally, TASK1 and Kv1.4 $\mathrm{K}^{+}$channels are expressed in fasciculata cells

is not believed to be stored within the cells. Probably, a variety of non-genomic effects of $\mathrm{Ca}^{2+}$ underlies this fast response, e.g., an increase of intracellular $\mathrm{Ca}^{2+}$ stimulates the activity of StAR $[21,76]$ and is paralleled by an influx of $\mathrm{Ca}^{2+}$ into the mitochondria [144]. A rise in mitochondrial $\mathrm{Ca}^{2+}$ enhances the availability of NAPDH, a cofactor of several steroidogenic enzymes $[107,113]$. As a negative feedback, an increase of intracellular $\mathrm{Ca}^{2+}$ activates $\mathrm{Ca}^{2+}$-regulated $\mathrm{K}^{+}$channels, 
which hyperpolarize the membrane, thereby preventing overwhelming aldosterone secretion. Chronic stimulation of aldosterone production elicits trophic effects on the adrenal gland. Long-term treatment of rats with Ang-II or a low $\mathrm{Na}^{+}$diet induces proliferation and hypertrophy of aldosteroneproducing glomerulosa cells $[88,114]$.

ACTH acts at least in two ways on adrenocortical cells; it acutely stimulates cortisol (and aldosterone) secretion, and it promotes cell proliferation and differentiation of glomerulosa and fasciculata cells [131, 134]. With regard to aldosterone secretion, the acute effect of ACTH is mainly mediated via an increased supply of cholesterol, the precursor of steroid hormones [54]. In addition, ACTH facilitates voltage-gated $\mathrm{Ca}^{2+}$ channel opening probably by direct phosphorylation and indirectly via inhibition of $\mathrm{K}^{+}$channels leading to depolarization $[38,39,41,44,81,124,136]$. In bovine and human fasciculata cells, ACTH is a negative regulator of TREK1. TREK1 is also expressed in bovine cells from zona glomerulosa and in human adrenocortical NCI-H295R cells $[14,36,80]$. Inactivation of TREK1 in NCI-H295R cells induces a depolarization [14]. By contrast, native primary cultured human glomerulosa cells do not show $\mathrm{K}^{+}$currents resembling TREK1 [102]. Trek1 is also expressed in mouse adrenocortical cells (UniGene data), but an adrenal phenotype of the Trek1 knockout mouse has not yet been reported $[56,91,142]$.

\section{Adrenocortical cells are excitable}

Cultured primary cells or adrenocortical cell lines display a very high $\mathrm{K} 2 \mathrm{P} \mathrm{K}^{+}$channel activity which is inhibited by AngII. The inhibition of these $\mathrm{K}^{+}$channels depolarizes the membrane and triggers the activation of voltage-gated $\mathrm{Ca}^{2+}$ channels and hormone synthesis. Dispersed and cultured adrenocortical cells are considered non-excitable cells; they usually do not display action potentials. However, experiments under more physiological conditions, e.g., on fresh adrenal slices, have disclosed that native adrenocortical cells are excitable with rapid oscillations of membrane voltage and intracellular $\mathrm{Ca}^{2+}[58,103,109,115]$. In slice preparations, Ang-IIinduced $\mathrm{Ca}^{2+}$ waves propagate from cell to cell suggesting functional coupling of adrenocortical cells via gap junctions [103]. Most likely, oscillatory activity of $\mathrm{K}^{+}$and $\mathrm{Ca}^{2+}$ channels and $\mathrm{Ca}^{2+}$-transporting systems is the molecular correlate of these oscillations. The absence of $\mathrm{Ca}^{2+}$ oscillations in most adrenocortical cell lines and adrenal primary cells suggests that adrenal-specific cell differentiation and electrical properties are not sufficiently preserved in these "model systems".

What is the possible role of $\mathrm{K}^{+}$channels without oscillatory activity, such as K2P, in excitable adrenocortical cells? As mentioned above, the activity of $\mathrm{K}^{+}$channels is essential for hyperpolarizing the membrane voltage at resting conditions, and it allows glomerulosa cells to act as sensors of extracellular $\mathrm{K}^{+}$. Constitutively, active $\mathrm{K}^{+}$channels ensure the hyperpolarized membrane voltage that is required for hyperpolarization-dependent extrusion of $\mathrm{Ca}^{2+}$, e.g., via $\mathrm{Na}^{+} / \mathrm{Ca}^{2+}$ exchangers. Moreover, these $\mathrm{K}^{+}$channels determine the level of excitability of adrenocortical cells and the frequency of action potentials, reminiscent of the role of $\mathrm{K}_{\mathrm{ATP}} \mathrm{K}^{+}$ channels in insulin-secreting cells. In pancreatic beta cells, $\mathrm{K}_{\mathrm{ATP}}$ channel inhibition is induced by rises of the ATP/ADP ratio and results in membrane depolarization, action potentials, and oscillations of intracellular $\mathrm{Ca}^{2+}[60]$. In a similar way, $\mathrm{Ca}^{2+}$ oscillations in adrenal glomerulosa cells are triggered by Ang-II-induced inhibition of K2P channels. This function of adrenal K2P channels is important for the regulation of aldosterone synthesis under physiological and pathophysiological conditions [58].

\section{Other factors controlling aldosterone secretion}

Besides the main regulators (Ang-II, high plasmatic $\mathrm{K}^{+}$concentrations, ACTH), a variety of other mediators modulate aldosterone secretion, e.g., serotonin, endothelin-1 [129]. Over the last decades, the pathways stimulating aldosterone secretion have been in the focus of research activities. Conversely, mechanisms that inhibit the synthesis of aldosterone and prevent excessive secretion are also important e.g., atrial natriuretic peptide (ANP)-induced inhibition of StAR expression [20], ANP-mediated activation of $\mathrm{Ca}^{2+}$-dependent MaxiK (KCNMA1) $\mathrm{K}^{+}$channels [46], activation of voltagegated $\mathrm{K}^{+}$channels such as KCNQ1, as well as $\mathrm{Na}^{+}$- and $\mathrm{G}$ protein-dependent activation of Kir3.4 $(\mathrm{KCNJ} 5) \mathrm{K}^{+}$channels. These $\mathrm{K}^{+}$channels have in common that their activation hyperpolarizes the membrane thereby reducing $\mathrm{Ca}^{2+}$ influx and aldosterone secretion. Other regulatory pathways involve the control of $\mathrm{Na}^{+} / \mathrm{K}^{+}$ATPase activity and of transport systems lowering intracellular $\mathrm{Ca}^{2+}$, e.g., $\mathrm{Na}^{+} / \mathrm{Ca}^{2+}$ exchangers (NCX and NCKX) and $\mathrm{Ca}^{2+}$ ATPases [11, 133]. In addition to acute effects, a complex network of regulating factors controls cell proliferation, centripetal migration, and differentiation as well as apoptosis of adrenocortical cells [129].

\section{Regulation of cortisol/corticosterone synthesis}

Glucocorticoids affect a plethora of physiological functions, e.g., lipid and glucose metabolism and the immune system. Inappropriately, high cortisol production is a characteristic for Cushing's syndrome (hypercortisolism) [126]. Cortisol synthesis in fasciculata cells is mainly controlled by ACTH. Binding of ACTH to the $\mathrm{G}_{\mathrm{s}}$-protein-coupled melanocortin 2 receptor (MC2R) activates adenylate cyclase leading to increased cAMP synthesis. Activated by cAMP, protein 
kinase A (PKA) phosphorylates several target proteins. Two of these target proteins improve the supply with cholesterol: cholesterol ester hydrolase $(\mathrm{CEH})$ releases cholesterol from esterified cholesterol in intracellular lipid droplets [125], and StAR shuttles cholesterol into the inner mitochondrial membrane. Moreover, PKA phosphorylates transcription factors that stimulate expression of the 11ß-hydroxylase (CYP11B1), the enzyme catalyzing the final step of glucocorticoid synthesis [47, 127]. The central role of PKA signaling for cortisol synthesis was recently underlined by the observation that a somatic gain-of-function mutation of PKA is present in about $50 \%$ of patients with cortisol-producing adrenal adenomas $[12,15,47,117]$. Another target of PKA is the K2P channel TREK1 that is inhibited by phosphorylation [39]. Due to inhibition of TREK1, ACTH stimulation leads to depolarization of fasciculata cells and activation of voltage-dependent $\mathrm{Ca}^{2+}$ channels [39]. One might speculate that chronic TREK1 inhibition contributes to the pathophysiology of cortisolproducing adenoma cells carrying the gain-of-function mutation of PKA. Interestingly, the Trekl knockout mouse does not present with obvious signs of Cushing's syndrome suggesting that Trek1 inhibition increases glucocorticoid secretion only in the presence of other stimulating factors.

Why are such mutations enhancing cAMP-dependent pathways not detected in aldosterone-producing adenomas? Adrenocortical cells undergo a centripetal migration and differentiation starting from capsular and subcapsular stem cells and ending up by apoptosis at the border between the adrenal cortex and medulla. The subcapsular-medullar migration is accompanied by a shift of differentiation from the glomerulosa to the fasciculata cell type [43]. ACTH influences these important processes: ACTH stimulates proliferation and accelerates centripetal differentiation of adrenocortical cells [131]. On the other hand, suppression of ACTH by dexamethasone decreases proliferation and differentiation [131]. Thus, alterations of the cAMP/PKA pathway will most likely effect proliferation, migration, and differentiation of adrenocortical cells. One might speculate that in glomerulosa cells, mutational activation of PKA will probably cause an accelerated differentiation. Thus, adenomas originating from glomerulosa cells with constitutively active PKA might be phenotypical classified as cortisol secreting tumors. Further studies are needed to test this hypothesis.

Besides activating aldosterone secretion, Ang-II also stimulates synthesis of cortisol in bovine and human fasciculata cells $[39,40]$. Fasciculata cells display similar oscillations of the membrane potential as it was described for glomerulosa cells [8, 58, 94, 108]. Via inhibition of K2P channels, Ang-II depolarizes fasciculata cells resulting in activation of voltagedependent $\mathrm{Ca}^{2+}$ channels. These synergistic effects of ACTH and Ang-II on cortisol secretion might be of particular importance under stress conditions when a strong increase of cortisol secretion is needed.

\section{Mutations of ion-transporting membrane proteins are associated with aldosterone-producing adenomas}

The regulation of membrane voltage and cytosolic $\mathrm{Ca}^{2+}$ activity is central for the physiological control of aldosterone secretion. Disturbed function of proteins controlling membrane voltage and $\mathrm{Ca}^{2+}$ homeostasis can cause adrenal diseases. The importance of the control of membrane voltage and intracellular ion composition is exemplified by somatic mutations of $\mathrm{K}^{+}$channels, $\mathrm{Ca}^{2+}$ channels, the $\mathrm{Na}^{+} / \mathrm{K}^{+}$-ATPase, and a plasma membrane $\mathrm{Ca}^{2+}$-ATPase found in aldosteroneproducing adenomas [3]. The most frequently mutated gene is the inwardly rectifying $\mathrm{K}^{+}$channel Kir3.4 (KCNJ5). About $40 \%$ of adrenal adenomas show somatic mutations of Kir3.4 $[13,42,122]$. These mutations confer a pathological $\mathrm{Na}^{+}$ conductance ("gain-of-function") to the channel that depolarizes the cells and activates autonomous aldosterone synthesis and proliferation [17, 22, 70, 92, 93, 99, 123, 133]. Although these results clearly established the link between Kir3.4 mutations and hyperaldosteronism, the physiological role of nonmutated Kir3.4 in the adrenal cortex is still largely elusive. The wild-type Kir3.4 channel seems to be inactive in human adrenal cells under resting conditions [66, 70, 133]. Probably, Kir3.4 modulates the membrane potential of human glomerulosa cells after stimulation of aldosterone synthesis and prevents excess secretion of aldosterone [98]. Unfortunately, Kir3.4 function cannot be studied in mice because the channel is not expressed in the mouse adrenal gland (unpublished data).

\section{Adrenal phenotype of Task channel knockout mice}

Different knockout mouse models were used to investigate the relevance of Task 1 and Task $3 \mathrm{~K}^{+}$channels for the adrenal gland $[7,28,34,51,55,103]$. Mice with single deletions of the Task1 [55] or Task3 gene [7, 51, 103] as well as Task1/ Task3 double knockout mice displayed disturbances of the steroid hormone homeostasis [28]. A common feature of all these models was the partially autonomous aldosterone synthesis. The severity of the phenotype of the mice was dependent on the inactivated gene. Detailed analysis of the different phenotypes revealed that both $\mathrm{K}^{+}$channels, Task 1 and Task3, are necessary for normal control of aldosterone synthesis. Moreover, each Task $\mathrm{K}^{+}$channel seems to play a specific role for the sex- and age-dependent regulation of adrenocortical cell function.

\section{Adrenal phenotype of Task ${ }^{-/-}$mice}

In adrenal glands of rats and mice, Task 1 is expressed in cells of zona glomerulosa and zona fasciculata $[27,28,55]$. Besides 
this adrenal localization, Task1 is also expressed in the brain, the heart, and vascular tissue. The neurological phenotype of Task $^{-/-}$mice is rather mild $[2,32,77,78,90]$. In addition, Task 1 is expressed in the carotid bodies where it is involved in the chemosensory control of breathing [135]. The characterization of the cardiac phenotype of Task $1^{-/-}$mice $[29,31]$ as well as genetic studies identifying genetic TASK1 variations associated with arrhythmia [73] reveals the regulatory role of TASK1 channels in the cardiac conduction system. In humans, several mutations of TASK1 are associated with autosomal dominant pulmonary hypertension [85].

In mice, aldosterone secretion is strongly altered by deletion of the Task1 gene [55]. Interestingly, the adrenal phenotype of adult mice is restricted to females, which present a severe primary hyperaldosteronism with low plasma renin and hypokalemia. Female Task $1^{-/-}$mice are not able to adapt their remarkably high aldosterone levels to different salt diets, which normally increase (low $\mathrm{Na}^{+}$or high $\mathrm{K}^{+}$diet) or decrease (high $\mathrm{Na}^{+}$diet) plasma aldosterone. Similar to patients with hyperaldosteronism, female Taskl $1^{-/-}$mice develop arterial hypertension. Treatment with the mineralocorticoid receptor blocker canrenoate leads to normalization of the blood pressure corroborating the link between hyperaldosteronism and hypertension in these animals.

According to the model for the regulation of aldosterone synthesis, the deletion of Task1 leads to cell membrane depolarization, increased cytosolic $\mathrm{Ca}^{2+}$ activity, and increased transcription of aldosterone synthase (Cyp11b2). Indeed, female Task1 $1^{--}$mice show increased messenger RNA (mRNA) and protein expression of aldosterone synthase. The histomorphological basis for the sex-specific hyperaldosteronism, however, is surprising. Glomerulosa cells of female Task1 $1^{-1-}$ mice are devoid of aldosterone synthase (as measured by immunofluorescence). Instead, female Task $1^{-1}$ show a strong expression of aldosterone synthase in zona fasciculata cells. The pathological localization of aldosterone synthase suggests a profoundly disturbed zonation of the adrenal cortex. But surprisingly, the localization of the glomerulosa marker Dab2 is preserved, and corticosterone synthesis is also normal in Task1 $1^{-/}$mice. Apparently, the "dezonation" is restricted to specific cellular properties such as the ectopic expression of the aldosterone synthase and does not reflect a totally disturbed adrenocortical zonal architecture. Moreover, treatment of female Taskl ${ }^{-/-}$mice with the synthetic glucocorticoid dexamethasone strongly suppressed the hyperaldosteronism. This suppression of aldosterone secretion might be caused by direct effects of dexamethasone on fasciculata cells $[52,67]$ or via suppression of ACTH. In Task $1^{-1-}$ fasciculata cells, ACTH might act as a permissive factor for the abnormal expression of the aldosterone synthase. This is reminiscent of a glucocorticoid-remediable form of familial hyperaldosteronism (FH-I), which is caused by a CYP11B1/CYP11B2 chimeric gene expressed under the control of ACTH [75]. In which way could ACTH modulate the phenotype of female Task1 $1^{-1-}$ mice? Via inhibition of Trek1, ACTH probably depolarizes the plasma membrane $[38,39,41,81]$. In mice lacking Taskl, the ACTH-induced depolarization could be more pronounced and sufficient to elicit ectopic expression of aldosterone synthase. In addition, effects of ACTH on cell proliferation and differentiation could influence the severity of the phenotype in female Task $1^{-/-}$mice.

\section{Age-dependent phenotype of Task ${ }^{-/-}$mice}

Before puberty, the mislocalization of aldosterone synthase in the zona fasciculata was observed in Taskl ${ }^{-1-}$ mice of both sexes. After puberty, male Task $1^{-/-}$mice restored the normal glomerulosa-specific localization of aldosterone synthase and normal plasma aldosterone levels, while female Task $1^{-/-}$mice maintained the ectopic expression of the aldosterone synthase and the hyperaldosteronism phenotype. The compensation of the Task 1 invalidation in male mice after puberty was probably driven by androgen-dependent mechanisms. Castration of young male $\mathrm{Task1}^{-/-}$mice prevented restoration of glomerulosa-specific localization of aldosterone synthase as seen in adult male Task $1^{-1-}$ mice. Accordingly, treatment of female Task1 $1^{-1}$ mice with testosterone led to the disappearance of aldosterone synthase from fasciculata cells and to a normal expression in glomerulosa cells [55]. Different factors possibly contribute to the compensation of the Task1 deletion in male mice or testosterone treated female mice. Adult male mice exhibit a higher expression of Task3 [55], Trekl, and Kcnq1 (unpublished data) $\mathrm{K}^{+}$channels than female mice. In addition, Task 3 protein expression in male mice was found in zona glomerulosa and zona fasciculata, while it seems to be largely restricted to zona glomerulosa in female mice [103].

\section{Adrenal phenotype of Task $1^{-/-} /$Task $^{-/-}$double knockout mice}

The possible role of Task 3 as a compensatory factor for Task 1 deletion in male mice was tested by analysis of the adrenal phenotype of mice with a double knockout of the Task 1 and Task3 genes [28]. However, male Task ${ }^{-1-} /$ Task $^{-1-}$ mice do not develop ectopic expression of aldosterone synthase as observed in female Task $1^{-/}$mice. Although those male double knockout mice display hyperaldosteronism, while male Task $1^{-/-}$mice do not, the normal glomerulosa-specific localization of the aldosterone synthase is retained. Apparently, Task3 is not the sole androgen-dependent factor that 
establishes a normal distribution of aldosterone synthase in the adrenal cortex of mice lacking Task1.

In patch-clamp measurements, native glomerulosa cells from male Task $1^{-/-} /$Task $^{-/-}$mice have no Task-like currents and are severely depolarized. As a consequence, plasma aldosterone levels in male Task1 $1^{-/} /$Task $^{-/-}$mice are increased. Normally, high $\mathrm{Na}^{+}$diet suppresses plasma renin levels and, thereby, aldosterone secretion. In Task $1^{-/} /$Task $^{-/-}$mice, high $\mathrm{Na}^{+}$diet does not lead to the physiological suppression of aldosterone synthesis. In these mice, plasma renin levels are already suppressed under normal diet, and a further suppression by high $\mathrm{Na}^{+}$intake is not possible. These results indicate that Task $3 \mathrm{~K}^{+}$channels are needed for a normal control of aldosterone synthesis in glomerulosa cells, but they are not essential for the suppression of aldosterone synthase expression in zona fasciculata.

\section{Effect of acidosis on aldosterone secretion of Task knockout mice}

Besides Ang-II and high plasma $\mathrm{K}^{+}$, acidosis is known to stimulate aldosterone synthesis [53, 110, 119, 120]. Task1 and Task $3 \mathrm{~K}^{+}$channels are inhibited by extracellular acidification $[26,27,33]$. Therefore, Guagliardo et al. hypothesized that Task $1^{-1-} /$ Task $^{-/-}$mice exhibit an altered response of aldosterone secretion upon $\mathrm{NH}_{4} \mathrm{Cl}$-induced acidosis [50]. Interestingly, stimulation of aldosterone production by mild acidosis, as observed in wild-type mice, was not completely abrogated in Task $1^{-/-} /$Task $^{-/-}$mice. Apparently, Task 1 and Task 3 channels are not essential for the stimulatory effect of acidosis on aldosterone secretion. Most likely, acidosis has a dual effect; it stimulates the renin/Ang-II system, and it has a direct effect on adrenal $\mathrm{K}^{+}$channels.

\section{Expression of Dkk3 modulates the adrenal phenotype of male TaskI $^{-/-}$mice}

The androgen-dependent compensatory mechanism in male Task $1^{-1-}$ mice is presumably complex and probably involves several factors on different levels of the signaling cascade. In order to identify those factors, El Wakil et al. performed a gene chip analysis [34] to investigate potential changes of adrenal mRNA expression in Task $1^{-/-}$mice with ectopic aldosterone expression. The most appealing differentially regulated factor was dickkopf-3 (Dkk3). Dkk3 is a member of the dickkopf family and modulates the Wnt/B-catenin pathway, which is involved in the control of glomerulosa cell function and differentiation in mouse adrenal glands [35]. Dkk3 is expressed in the zona glomerulosa of humans and mice [132], and its expression is stimulated by cytosolic $\mathrm{Ca}^{2+}$ [34]. The function of Dkk3 is to inhibit aldosterone synthesis
[18], and therefore, it could be a factor counterbalancing the hyperaldosteronism of Task ${ }^{-/-}$mice. A possible role of Dkk3 for the compensation of the Task1 deletion in male mice was verified by phenotyping Task $1^{-/-} / D k k 3^{-/-}$double knockout mice [34]. Similar to female Task1 $1^{-1-}$ mice [55], male Task $1^{-/-} / D k k 3^{-/}$mice showed increased plasma aldosterone levels, which were not further stimulated by a $\mathrm{K}^{+}$-rich diet. The expression of Cyp11b2 mRNA was increased, but the localization of the aldosterone synthase was still restricted to the zona glomerulosa. Obviously, Dkk3 functions as a repressor of Cyp11b2 expression in glomerulosa cells, but it is not essential for suppression of aldosterone synthase expression in zona fasciculata in male $\mathrm{Task}^{-/-}$mice.

\section{The adrenal phenotype of Task $3^{-/-}$mice}

The specific role of Task $3 \mathrm{~K}^{+}$channels for adrenocortical function was investigated using two different Task $3^{-/-}$mouse models $[51,103]$. Under high $\mathrm{Na}^{+}$diet, adult Task $3^{-/-}$animals do not show the physiological suppression of aldosterone secretion and develop salt-sensitive arterial hypertension [51, 103]. What is the explanation for the lack of adaptation to high dietary $\mathrm{Na}^{+}$intake? Normally, high $\mathrm{Na}^{+}$intake leads to a decrease of the renin and Ang-II levels and to a suppression of aldosterone. In Task $3^{-/-}$mice, aldosterone secretion is partially autonomous and does not require stimulation by renin/Ang-II. Under normal diet, the autonomous component of aldosterone secretion is masked by a compensatory suppression of renin/Ang-II and a reduction of Ang-II-driven aldosterone secretion. At high $\mathrm{Na}^{+}$diet, a further suppression of renin/Ang-II is not possible. With regard to the high $\mathrm{Na}^{+}$ intake, aldosterone stays inappropriately high, $\mathrm{Na}^{+}$is retained in a pathological way, and arterial hypertension develops. Accordingly, the aldosterone/renin ratio, a clinical indicator for autonomous aldosterone production, is strongly increased under a control diet and a high $\mathrm{Na}^{+}$diet in Task $3^{-/-}$mice. In contrast to the ectopic expression of aldosterone synthase in female Task $1^{-/-}$mice, Task $3^{-/}$mice of both sexes display normal localization of aldosterone synthase in zona glomerulosa [103]. Obviously, invalidation of the Task3 gene affects the physiological control of aldosterone production, but functional differentiation and zonation of the adrenal cortex are maintained.

Interestingly, Guagliardo et al. observed a hyperpolarized membrane voltage in glomerulosa cells of fresh adrenal slices of Task $3^{-1-}$ mice, although Task 3 is believed to be an important $\mathrm{K}^{+}$channel of these cells [51]. How can this surprising observation be explained? In contrast to Guagliardo et al., we found primary cultured adrenocortical cells of Task ${ }^{-/-}$mice depolarized to $-50 \mathrm{mV}$ compared to $-80 \mathrm{mV}$ in wild-type cells. However, after stimulation with Ang-II, primary cells of Task $3^{-/-}$mice did not show the expected depolarization; they 
hyperpolarized transiently, probably due to enhanced activity of $\mathrm{Ca}^{2+}$-activated $\mathrm{K}^{+}$channels (unpublished data). Most likely, the increased activity of $\mathrm{Ca}^{2+}$-activated $\mathrm{K}^{+}$channels in glomerulosa cells of Task $3^{-1-}$ mice compensates for the loss of Task3 and masks the electrical phenotype under certain experimental conditions.

To gain further insights into the role of Task 3 for adrenal signaling, intracellular $\mathrm{Ca}^{2+}$ was measured in freshly prepared adrenal slices [103]. Slices of wild-type mice showed a spontaneous $\mathrm{Ca}^{2+}$ oscillation only in a small number of cells, most of the cells were silent. After stimulation with Ang-II or high extracellular $\mathrm{K}^{+}$, most of the wild-type cells showed high frequency $\mathrm{Ca}^{2+}$ oscillations. By contrast, in slices of Task $^{-/-}$mice, glomerulosa cells often showed spontaneous $\mathrm{Ca}^{2+}$ oscillations under control conditions, but the stimulatory effects of Ang-II and high extracellular $\mathrm{K}^{+}$were attenuated [103].

From these $\mathrm{Ca}^{2+}$ measurements on adrenal slices, we expected impaired aldosterone response of Task $3^{-/}$mice in vivo at high $\mathrm{K}^{+}$diet and low $\mathrm{Na}^{+}$diet (the latter increases renin and Ang-II). Surprisingly, glomerulosa cell of Task $3^{-/-}$mice still showed a normal increase of aldosterone production under low $\mathrm{Na}^{+}$and high $\mathrm{K}^{+}$diets $[51,103]$. Despite the impaired effects of Ang-II and high $\mathrm{K}^{+}$in the slice preparation, the adrenal responsiveness towards major stimulatory pathways appears to be preserved in Task $3^{-/-}$mice, allowing aldosterone to increase normally in response to these strong stimuli. Probably, several compensatory mechanisms act in concert to counterbalance the impaired membrane and $\mathrm{Ca}^{2+}$ signaling. For instance, $\mathrm{Ca}^{2+}$-independent signaling pathways (e.g., via lipoxygenase and activation of p38-MAPK $[49,100])$ could contribute to the preserved Ang-II effect on aldosterone production. Moreover, an increase of the plasma $\mathrm{K}^{+}$concentration could activate $\mathrm{K}^{+}$-sensitive adrenomedullary cells which stimulate glomerulosa cells via paracrine factors [10] or via nerve fibers projecting into the adrenal cortex [24].

\section{Severe hyperaldosteronism in newborn Task $^{-/-}$mice}

The adrenal phenotype of $\operatorname{Task}^{-/-}$mice is age-dependent [7]. Newborn Task3 $3^{-1-}$ mice have a more severe hyperaldosteronism than adult mice. In addition, plasma concentrations of other steroid hormones such as corticosterone and progesterone are increased and transcription of steroidogenic enzymes, e.g., aldosterone synthase and hydroxy- $\beta-5-$ steroiddehydrogenase, $3 \beta$-and steroid $\beta$-isomerase 6 (Hsd3b6, an enzyme needed for glomerulosa-specific progesterone synthesis), is enhanced.

A gene chip analysis was performed to identify transcriptionally regulated potential factors and pathways underlying the transient hyperaldosteronism of neonatal $\mathrm{Task}^{-/-}$mice. This analysis revealed a strong but transient upregulation of renin mRNA in adrenal glands of 1-day-old Task $3^{-/-}$mice; in 12-day-old animals, renin expression was back to control values. The renin expressing cells were localized in zona fasciculata. Local renin expression in the adrenal gland and in other extra-renal tissues (e.g., in the heart and the eye) is known for a long time [101]. The exact function of the local adrenal renin/Ang-II system is not well understood. It was suggested that local renin has a role for the regulation of tissue function independently of or synergistically with the systemic (renal) renin signaling [104]. In mice, adrenal renin is normally detected during fetal development, but it disappears at the time of birth $[64,68]$. Interestingly, adrenal renin expression can be activated under several conditions. Aldosterone synthase knockout mice show abnormal renin expression in the adrenal gland [71]. In adult rats, renin can be found in glomerulosa cells and appears to be involved in the regulation of aldosterone synthesis. Local renin is upregulated after nephrectomy and after stimulation with Ang-II, high $\mathrm{K}^{+}$, and ACTH [30, 61, 105, 141]. The cellular signaling mechanisms translating these conditions and stimuli into increased renin expression, however, are not known. Moreover, it is not clear which pathways are involved to link the loss of Task 3 channels to the abnormal renin expression in fasciculata cells and how local renin stimulates steroid hormone secretion.

Why is the hyperaldosteronism phenotype of neonatal Task $^{-/-}$mice transient in nature? To address this question, gene chip analyses of 1- and 12-day-old Task $3^{-/-}$mice were used. The comparison of the results at the two time points revealed several age-dependently expressed genes that are known modulators of adrenal function [7]. For instance, the expression of the nicotinamide nucleotide transhydrogenase, which produces NAPDH as a cofactor for Cyp-enzymes, decreased over time [89, 128]. Similarly, the expression of the store-operated $\mathrm{Ca}^{2+}$ channel $\operatorname{Trpc5}$, which is possibly involved in the generation of the Ang-II dependent $\mathrm{Ca}^{2+}$ signal $[57,74]$, was decreased in 12-day-old Task $^{-/}$mice. Other factors such as galanin, a neuropeptide stimulating glucocorticoid secretion, showed enhanced expression with age. Most likely, a complex network of factors and pathways counterbalance the cellular deficit induced by the inactivation of Task3, and apparently, this compensatory mechanisms take time to fully develop.

\section{Task1 and Task 3 channels serve distinct functions}

Task 1 and Task 3 are related $\mathrm{K}^{+}$channels and probably assemble to form Task1-Task3 heterodimers [25]. One might assume that the two channels serve a similar cellular function. However, the tissue distribution of mRNA expression is not identical and genetic inactivation of each of these channels in mice led to different adrenal phenotypes (Table 2). It appears that an important function of Task 1 is to prevent the 


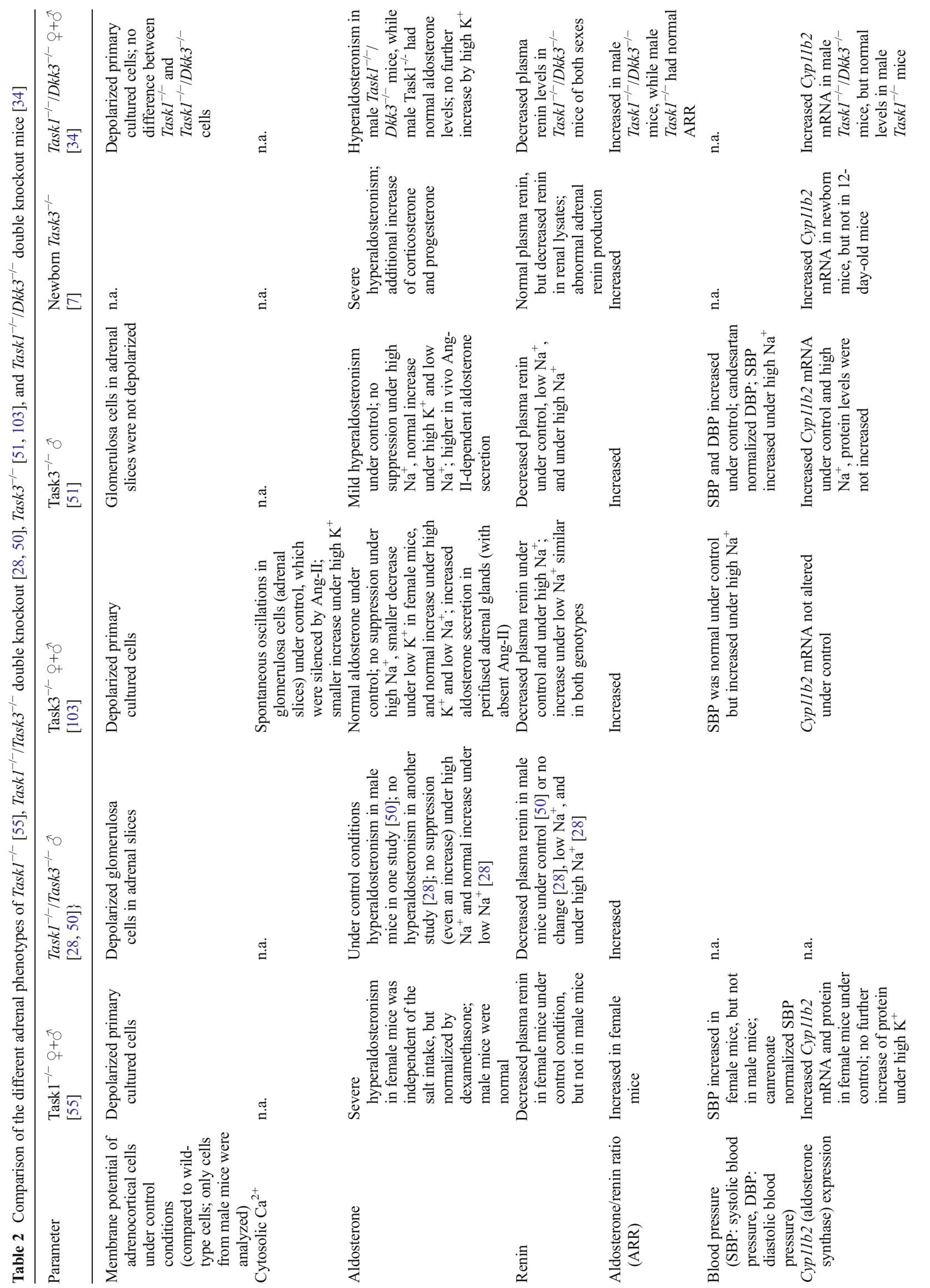




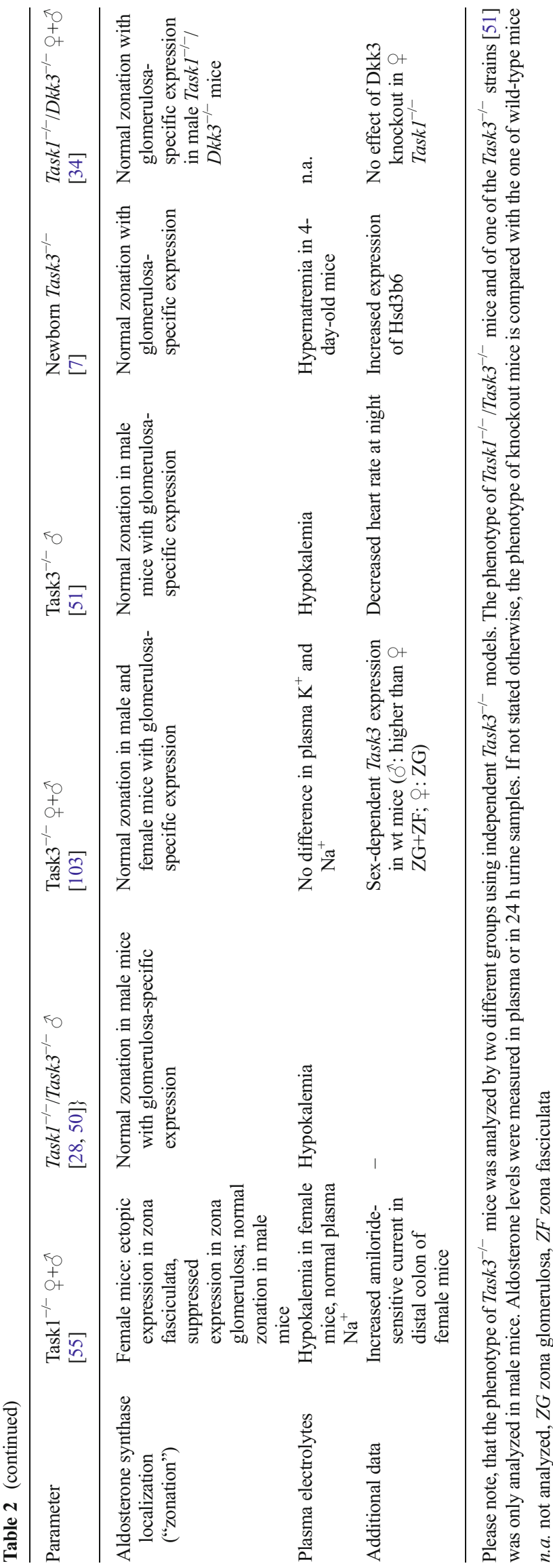

expression of the aldosterone synthase in fasciculata cells, thereby restricting aldosterone synthase expression to glomerulosa cells. In female Task $1^{-1-}$ mice, the most striking phenotype is the abnormal expression of aldosterone synthase in fasciculata cells that causes severe hyperaldosteronism [55]. In adult Task1 $1^{-1-}$ males, the presence of Task3 in fasciculata cells may contribute to the correction of this phenotype after puberty, but it is certainly not essential, because adult male Task $1^{-/} /$Task3 $^{-/-}$mice also display a normal Cyp11b2 expression pattern [28]. Interestingly, glomerulosa cells of female Task1 ${ }^{-/-}$mice are still sensitive for negative feedback mechanisms in the presence of high plasma aldosterone: they completely shut off aldosterone synthase expression [55].

Probably, the major role of Task3 is setting the resting potential of mouse glomerulosa cells [103]. Also, in rat glomerulosa cells, Task3 homomers seem to be the dominant channel type ensuring the high resting potential $[25,26]$. In Task $^{-/-}$mice, aldosterone secretion becomes largely autonomous from the renin-angiotensin-axis, because the glomerulosa cells are depolarized even in the absence of Ang-II. Suppression of aldosterone secretion by low $\mathrm{K}^{+}$diet is also compromised, probably due to the inability of Task $3^{-/-}$ cells to hyperpolarize appropriately when extracellular $\mathrm{K}^{+}$is low [103]. In both Task1 ${ }^{-1-}$ and Task3 ${ }^{-1-}$ mice, the adrenal phenotypes are age-dependent with regard to the ectopic expression of aldosterone synthase and the severe hyperaldosteronism, respectively. In both knockout models, compensation becomes more effective with age and the severity of the symptoms decreases although an abnormal depolarization of the adrenocortical cells is still detectable in cells from adults. In the light of the genetic defects of the $\mathrm{K}^{+}$ channel $\mathrm{KCNJ} 5, \mathrm{Ca}^{2+}$ channels, and ion-transporting ATPases that are causative factors for the formation of aldosteroneproducing adenomas [42], it is surprising that the depolarized adrenal cortex of Task1 and Task3 knockout animals doesn't show adenomas or overt adrenal hyperplasia. Maybe the adrenal cell biology of Task1 and Task3 knockout animals is sufficiently dynamic to allow effective adaptation and prevention of hyperplasia - or the consequences of Task channel inactivation are not strong enough to cause obvious hyperplasia during the short lifespan of mice.

\section{Outlook: role of TASK channels for human adrenal pathology}

$\mathrm{Na}^{+}$-permeable gain-of-function mutations of KCNJ5 are causative for some $40 \%$ of aldosterone-producing adenomas [17, 22, 70, 92, 93, 123]. Are TASK channels also candidate genes for an increased risk of adrenal hyperplasia or adenoma formation in humans? Interestingly, TASK channels were reported to change their ion selectivity and to become permeable to $\mathrm{Na}^{+}$upon extracellular acidification [86]. However, up 
to now, no mutations of TASK channels have been found that increase the $\mathrm{Na}^{+}$permeability and cause aldosterone-producing adenomas. Perhaps, such permeability-changing TASK channel mutations, even if they occur, do not induce proliferation that is a prerequisite for adenoma formation. Loss-of-function mutations of TASK3 have been linked to Birk Barel mental retardation dysmorphism syndrome [9, 140]. It is, however, not known if these patients have an adrenal phenotype. Interestingly, TASK3 is a genomically imprinted gene showing paternal silencing [9]. Therefore, a mutation in the maternal copy of TASK3 can lead to a disease, while a mutation in the paternal allele will have no effect. In a genome-wide association study, a correlation of SNPs in the TASK3 gene with aldosterone levels and the risk for hypertension was found, but no difference between males and females was reported [65]. Also for TASK1, a human disease was linked to gene mutations. Loss-of-function mutations can cause pulmonary hypertension [85]. In addition, a single nucleotide polymorphism nearby the TASK1 gene was found to be associated with blood pressure [45], but no adrenal phenotype was reported so far. It is possible that mutations of TASK genes can be compensated and do not cause phenotypes strong enough to provoke monogenetic human adrenal diseases. Further studies are required to investigate a potential role of TASK channels as modifier genes of adrenocortical disorders.

Disclosure statement The authors have nothing to disclose.

Funding The study was supported by the Deutsche Forschungsgemeinschaft (FOR1086 to R.W. and S.B.), by the French Agence Nationale pour la Recherche (ANR) BeyondTASKs grant (JB and EL), and LabEx Ion Channel Science and Therapeutics grant (ANR11-LABX-0015-01, to JB).

Open Access This article is distributed under the terms of the Creative Commons Attribution License which permits any use, distribution, and reproduction in any medium, provided the original author(s) and the source are credited.

\section{References}

1. Akizuki O, Inayoshi A, Kitayama T, Yao K, Shirakura S, Sasaki K, Kusaka H, Matsubara M (2008) Blockade of T-type voltage-dependent $\mathrm{Ca} 2+$ channels by benidipine, a dihydropyridine calcium channel blocker, inhibits aldosterone production in human adrenocortical cell line NCI-H295R. Eur J Pharmacol 584:424-434

2. Aller MI, Veale EL, Linden AM, Sandu C, Schwaninger M, Evans LJ, Korpi ER, Mathie A, Wisden W, Brickley SG (2005) Modifying the subunit composition of TASK channels alters the modulation of a leak conductance in cerebellar granule neurons. J Neurosci 25:11455-11467

3. Al-Salameh A, Cohen R, Desailloud R (2014) Overview of the genetic determinants of primary aldosteronism. Appl Clin Genet 7:67-79

4. Arrighi I, Bloch-Faure M, Grahammer F, Bleich M, Warth R, Mengual R, Drici MD, Barhanin J, Meneton P (2001) Altered potassium balance and aldosterone secretion in a mouse model of human congenital long QT syndrome. Proc Natl Acad Sci U S A 98: 8792-8797
5. Azizan EA, Lam BY, Newhouse SJ, Zhou J, Kuc RE, Clarke J, Happerfield L, Marker A, Hoffman GJ, Brown MJ (2012) Microarray, qPCR, and KCNJ5 sequencing of aldosteroneproducing adenomas reveal differences in genotype and phenotype between zona glomerulosa- and zona fasciculata-like tumors. J Clin Endocrinol Metab 97:E819-E829

6. Bandulik S, Penton D, Barhanin J, Warth R (2010) TASK1 and TASK3 potassium channels: determinants of aldosterone secretion and adrenocortical zonation. Horm Metab Res 42: 450-457

7. Bandulik S, Tauber P, Penton D, Schweda F, Tegtmeier I, Sterner C, Lalli E, Lesage F, Hartmann M, Barhanin J, Warth R (2013) Severe hyperaldosteronism in neonatal Task3 potassium channel knockout mice is associated with activation of the intraadrenal reninangiotensin system. Endocrinology 154:2712-2722

8. Barbara JG, Takeda K (1995) Voltage-dependent currents and modulation of calcium channel expression in zona fasciculata cells from rat adrenal gland. J Physiol 488(Pt 3):609-622

9. Barel O, Shalev SA, Ofir R, Cohen A, Zlotogora J, Shorer Z, Mazor G, Finer G, Khateeb S, Zilberberg N, Birk OS (2008) Maternally inherited Birk Barel mental retardation dysmorphism syndrome caused by a mutation in the genomically imprinted potassium channel KCNK9. Am J Hum Genet 83:193-199

10. Belloni AS, Malendowicz LK, Rucinski M, Guidolin D, Nussdorfer GG (2007) Galanin stimulates cortisol secretion from human adrenocortical cells through the activation of galanin receptor subtype 1 coupled to the adenylate cyclase-dependent signaling cascade. Int $\mathrm{J}$ Mol Med 20:859-864

11. Beuschlein F, Boulkroun S, Osswald A, Wieland T, Nielsen HN, Lichtenauer UD, Penton D, Schack VR, Amar L, Fischer E, Walther A et al (2013) Somatic mutations in ATP1A1 and ATP2B3 lead to aldosterone-producing adenomas and secondary hypertension. Nat Genet 45:440-444

12. Beuschlein F, Fassnacht M, Assie G, Calebiro D, Stratakis CA, Osswald A, Ronchi CL, Wieland T, Sbiera S, Faucz FR, Schaak $\mathrm{K}$ et al (2014) Constitutive activation of PKA catalytic subunit in adrenal Cushing's syndrome. N Engl J Med 370:1019-1028

13. Boulkroun S, Beuschlein F, Rossi GP, Golib-Dzib JF, Fischer E, Amar L, Mulatero P, Samson-Couterie B, Hahner S, Quinkler M, Fallo F et al (2012) Prevalence, clinical, and molecular correlates of KCNJ5 mutations in primary aldosteronism. Hypertension 59:592-598

14. Brenner T, O'Shaughnessy KM (2008) Both TASK-3 and TREK-1 two-pore loop $\mathrm{K}$ channels are expressed in H295R cells and modulate their membrane potential and aldosterone secretion. Am J Physiol Endocrinol Metab 295:E1480-E1486

15. Cao Y, He M, Gao Z, Peng Y, Li Y, Li L, Zhou W, Li X, Zhong X, Lei Y, Su T et al (2014) Activating hotspot L205R mutation in PRKACA and adrenal Cushing's syndrome. Science 344:913-917

16. Chai W, Danser AH (2006) Why are mineralocorticoid receptor antagonists cardioprotective? Naunyn Schmiedebergs Arch Pharmacol 374:153-162

17. Charmandari E, Sertedaki A, Kino T, Merakou C, Hoffman DA, Hatch MM, Hurt DE, Lin L, Xekouki P, Stratakis CA, Chrousos GP (2012) A novel point mutation in the KCNJ5 gene causing primary hyperaldosteronism and early-onset autosomal dominant hypertension. J Clin Endocrinol Metab 97:E1532-E1539

18. Chen M, Hornsby PJ (2006) Adenovirus-delivered DKK3/WNT4 and steroidogenesis in primary cultures of adrenocortical cells. Horm Metab Res 38:549-555

19. Chen X, Talley EM, Patel N, Gomis A, McIntire WE, Dong B, Viana F, Garrison JC, Bayliss DA (2006) Inhibition of a background potassium channel by Gq protein alpha-subunits. Proc Natl Acad Sci U S A 103:3422-3427

20. Cherradi N, Brandenburger Y, Rossier MF, Vallotton MB, Stocco DM, Capponi AM (1998) Atrial natriuretic peptide inhibits calcium- 
induced steroidogenic acute regulatory protein gene transcription in adrenal glomerulosa cells. Mol Endocrinol 12:962-972

21. Cherradi N, Brandenburger Y, Capponi AM (1998) Mitochondrial regulation of mineralocorticoid biosynthesis by calcium and the StAR protein. Eur J Endocrinol 139:249-256

22. Choi M, Scholl UI, Yue P, Bjorklund P, Zhao B, Nelson-Williams C, Ji W, Cho Y, Patel A, Men CJ, Lolis E et al (2011) K+ channel mutations in adrenal aldosterone-producing adenomas and hereditary hypertension. Science 331:768-772

23. Clark BJ, Pezzi V, Stocco DM, Rainey WE (1995) The steroidogenic acute regulatory protein is induced by angiotensin II and $\mathrm{K}+$ in H295R adrenocortical cells. Mol Cell Endocrinol 115:215-219

24. Costa JJ, Averill S, Ching YP, Priestley JV (1994) Immunocytochemical localization of a growth-associated protein (GAP-43) in rat adrenal gland. Cell Tissue Res 275:555-566

25. Czirjak G, Enyedi P (2002) Formation of functional heterodimers between the TASK-1 and TASK-3 two-pore domain potassium channel subunits. J Biol Chem 277:5426-5432

26. Czirjak G, Enyedi P (2002) TASK-3 dominates the background potassium conductance in rat adrenal glomerulosa cells. Mol Endocrinol 16:621-629

27. Czirjak G, Fischer T, Spat A, Lesage F, Enyedi P (2000) TASK (TWIK-related acid-sensitive $\mathrm{K}+$ channel) is expressed in glomerulosa cells of rat adrenal cortex and inhibited by angiotensin II. Mol Endocrinol 14:863-874

28. Davies LA, Hu C, Guagliardo NA, Sen N, Chen X, Talley EM, Carey RM, Bayliss DA, Barrett PQ (2008) TASK channel deletion in mice causes primary hyperaldosteronism. Proc Natl Acad Sci U S A 105:2203-2208

29. Decher N, Wemhoner K, Rinne S, Netter MF, Zuzarte M, Aller MI, Kaufmann SG, Li XT, Meuth SG, Daut J, Sachse FB et al (2011) Knock-out of the potassium channel TASK-1 leads to a prolonged QT interval and a disturbed QRS complex. Cell Physiol Biochem 28:77-86

30. Doi Y, Atarashi K, Franco-Saenz R, Mulrow PJ (1984) Effect of changes in sodium or potassium balance, and nephrectomy, on adrenal renin and aldosterone concentrations. Hypertension 6: I124-I129

31. Donner BC, Schullenberg M, Geduldig N, Huning A, Mersmann J, Zacharowski K, Kovacevic A, Decking U, Aller MI, Schmidt KG (2011) Functional role of TASK-1 in the heart: studies in TASK-1deficient mice show prolonged cardiac repolarization and reduced heart rate variability. Basic Res Cardiol 106:75-87

32. Du G, Chen X, Todorovic MS, Shu S, Kapur J, Bayliss DA (2011) TASK channel deletion reduces sensitivity to local anestheticinduced seizures. Anesthesiology 115:1003-1011

33. Duprat F, Lesage F, Fink M, Reyes R, Heurteaux C, Lazdunski M (1997) TASK, a human background $\mathrm{K}+$ channel to sense external $\mathrm{pH}$ variations near physiological $\mathrm{pH}$. EMBO J 16:5464-5471

34. El Wakil A, Bandulik S, Guy N, Bendahhou S, Zennaro MC, Niehrs C, Mari B, Warth R, Barhanin J, Lalli E (2012) Dkk3 is a component of the genetic circuitry regulating aldosterone biosynthesis in the adrenal cortex. Hum Mol Genet 21:4922-4929

35. El Wakil A, Lalli E (2011) The Wnt/beta-catenin pathway in adrenocortical development and cancer. Mol Cell Endocrinol 332:32-37

36. Enyeart JJ, Danthi SJ, Liu H, Enyeart JA (2005) Angiotensin II inhibits bTREK-1 $\mathrm{K}+$ channels in adrenocortical cells by separate $\mathrm{Ca} 2+-$ and ATP hydrolysis-dependent mechanisms. J Biol Chem 280:30814-30828

37. Enyeart JA, Danthi S, Enyeart JJ (2003) Corticotropin induces the expression of TREK-1 mRNA and $\mathrm{K}+$ current in adrenocortical cells. Mol Pharmacol 64:132-142

38. Enyeart JA, Danthi SJ, Enyeart JJ (2004) TREK-1 K+ channels couple angiotensin II receptors to membrane depolarization and aldosterone secretion in bovine adrenal glomerulosa cells. Am J Physiol Endocrinol Metab 287:E1154-E1165
39. Enyeart JJ, Enyeart JA (2013) Ca2+ and K+ channels of normal human adrenal zona fasciculata cells: properties and modulation by ACTH and AngII. J Gen Physiol 142:137-155

40. Enyeart JA, Liu H, Enyeart JJ (2009) Curcumin inhibits ACTH- and angiotensin II-stimulated cortisol secretion and $\mathrm{Ca}(\mathrm{v}) 3.2$ current. J Nat Prod 72:1533-1537

41. Enyeart JJ, Xu L, Danthi S, Enyeart JA (2002) An ACTH- and ATPregulated background $\mathrm{K}+$ channel in adrenocortical cells is TREK1. J Biol Chem 277:49186-49199

42. Fernandes-Rosa FL, Williams TA, Riester A, Steichen O, Beuschlein F, Boulkroun S, Strom TM, Monticone S, Amar L, Meatchi T, Mantero F et al (2014) Genetic spectrum and clinical correlates of somatic mutations in aldosterone-producing adenoma. Hypertension 64:354-361

43. Freedman BD, Kempna PB, Carlone DL, Shah MS, Guagliardo NA, Barrett PQ, Gomez-Sanchez CE, Majzoub JA, Breault DT (2013) Adrenocortical zonation results from lineage conversion of differentiated zona glomerulosa cells. Dev Cell 26:666-673

44. Gallo-Payet N, Grazzini E, Cote M, Chouinard L, Chorvatova A, Bilodeau L, Payet MD, Guillon G (1996) Role of Ca2+ in the action of adrenocorticotropin in cultured human adrenal glomerulosa cells. J Clin Invest 98:460-466

45. Ganesh SK, Chasman DI, Larson MG, Guo X, Verwoert G, Bis JC, Gu X, Smith AV, Yang ML, Zhang Y, Ehret G et al (2014) Effects of long-term averaging of quantitative blood pressure traits on the detection of genetic associations. Am J Hum Genet 95:49-65

46. Ganz MB, Nee JJ, Isales CM, Barrett PQ (1994) Atrial natriuretic peptide enhances activity of potassium conductance in adrenal glomerulosa cells. Am J Physiol 266:C1357-C1365

47. Goh G, Scholl UI, Healy JM, Choi M, Prasad ML, Nelson-Williams C, Kuntsman JW, Korah R, Suttorp AC, Dietrich D, Haase M et al (2014) Recurrent activating mutation in PRKACA in cortisolproducing adrenal tumors. Nat Genet 46:613-617

48. Grimm PR, Irsik DL, Settles DC, Holtzclaw JD, Sansom SC (2009) Hypertension of Kcnmb1-/- is linked to deficient K secretion and aldosteronism. Proc Natl Acad Sci U S A 106:11800-11805

49. Gu J, Wen Y, Mison A, Nadler JL (2003) 12-lipoxygenase pathway increases aldosterone production, 3',5'-cyclic adenosine monophosphate response element-binding protein phosphorylation, and p38 mitogen-activated protein kinase activation in H295R human adrenocortical cells. Endocrinology 144:534-543

50. Guagliardo NA, Yao J, Bayliss DA, Barrett PQ (2011) TASK channels are not required to mount an aldosterone secretory response to metabolic acidosis in mice. Mol Cell Endocrinol 336: $47-52$

51. Guagliardo NA, Yao J, Hu C, Schertz EM, Tyson DA, Carey RM, Bayliss DA, Barrett PQ (2012) TASK-3 channel deletion in mice recapitulates low-renin essential hypertension. Hypertension 59: 999-1005

52. Gummow BM, Scheys JO, Cancelli VR, Hammer GD (2006) Reciprocal regulation of a glucocorticoid receptor-steroidogenic factor-1 transcription complex on the Dax-1 promoter by glucocorticoids and adrenocorticotropic hormone in the adrenal cortex. Mol Endocrinol 20:2711-2723

53. Gyorke ZS, Sulyok E, Guignard JP (1991) Ammonium chloride metabolic acidosis and the activity of renin-angiotensin-aldosterone system in children. Eur J Pediatr 150:547-549

54. Hattangady NG, Olala LO, Bollag WB, Rainey WE (2012) Acute and chronic regulation of aldosterone production. Mol Cell Endocrinol 350:151-162

55. Heitzmann D, Derand R, Jungbauer S, Bandulik S, Sterner C, Schweda F, El Wakil A, Lalli E, Guy N, Mengual R, Reichold M et al (2008) Invalidation of TASK1 potassium channels disrupts adrenal gland zonation and mineralocorticoid homeostasis. EMBO J 27:179-187 
56. Heurteaux C, Guy N, Laigle C, Blondeau N, Duprat F, Mazzuca M, Lang-Lazdunski L, Widmann C, Zanzouri M, Romey G, Lazdunski M (2004) TREK-1, a K+ channel involved in neuroprotection and general anesthesia. EMBO J 23:2684-2695

57. Hong C, Kim J, Jeon JP, Wie J, Kwak M, Ha K, Kim H, Myeong J, Kim SY, Jeon JH, So I (2012) Gs cascade regulates canonical transient receptor potential 5 (TRPC5) through cAMP mediated intracellular $\mathrm{Ca} 2+$ release and ion channel trafficking. Biochem Biophys Res Commun 421:105-111

58. Hu C, Rusin CG, Tan Z, Guagliardo NA, Barrett PQ (2012) Zona glomerulosa cells of the mouse adrenal cortex are intrinsic electrical oscillators. J Clin Invest 122:2046-2053

59. Ibrahim HN, Hostetter TH (2003) Aldosterone in renal disease. Curr Opin Nephrol Hypertens 12:159-164

60. Inagaki N, Gonoi T, Clement JP, Namba N, Inazawa J, Gonzalez G, Aguilar-Bryan L, Seino S, Bryan J (1995) Reconstitution of IKATP: an inward rectifier subunit plus the sulfonylurea receptor. Science 270:1166-1170

61. Inagami T, Mizuno K, Naruse M, Nakamaru M, Naruse K, Hoffman LH, McKenzie JC (1989) Active and inactive renin in the adrenal. Am J Hypertens 2:311-319

62. Inoue M, Harada $\mathrm{K}$, Matsuoka $\mathrm{H}$, Naakamura $\mathrm{J}$ and Warashina $\mathrm{A}$ (2012) Mechanisms and roles of muscarinic activation in guinea-pig adrenal medullary cells. Am J Physiol Cell Physiol

63. Inoue M, Harada K, Matsuoka H, Sata T, Warashina A (2008) Inhibition of TASK1-like channels by muscarinic receptor stimulation in rat adrenal medullary cells. J Neurochem 106:1804-1814

64. Jones CA, Sigmund CD, McGowan RA, Kane-Haas CM, Gross KW (1990) Expression of murine renin genes during fetal development. Mol Endocrinol 4:375-383

65. Jung J, Barrett PQ, Eckert GJ, Edenberg HJ, Xuei X, Tu W, Pratt JH (2012) Variations in the potassium channel genes KCNK3 and $\mathrm{KCNK} 9$ in relation to blood pressure and aldosterone production: an exploratory study. J Clin Endocrinol Metab 97:E2160-E2167

66. Kienitz MC, Mergia E, Pott L (2014) The NCI-H295R cell line as in vitro model of hyperaldosteronism lacks funktional KCNJ5 (GIRK4; Kir3.4) channels. Acta Physiol 210:213-213, Abstract

67. Kim AC, Hammer GD (2007) Adrenocortical cells with stem/progenitor cell properties: recent advances. Mol Cell Endocrinol 265-266:10-16

68. Kon Y, Hashimoto Y, Kitagawa H, Sugimura M, Murakami K (1990) Renin immunohistochemistry in the adrenal gland of the mouse fetus and neonate. Anat Rec 227:124-131

69. Krapivinsky G, Gordon EA, Wickman K, Velimirovic B, Krapivinsky L, Clapham DE (1995) The G-protein-gated atrial $\mathrm{K}+$ channel IKACh is a heteromultimer of two inwardly rectifying $\mathrm{K}(+)$-channel proteins. Nature 374:135-141

70. Kuppusamy M, Caroccia B, Stindl J, Bandulik S, Lenzini L, Gioco F, Fishman V, Zanotti G, Gomez-Sanchez C, Bader M, Warth R et al. (2014) A novel KCNJ5-insT149 somatic mutation close to, but outside, the selectivity filter causes resistant hypertension by loss of selectivity for potassium. J Clin Endocrinol Metab 20141927:

71. Lee G, Makhanova N, Caron K, Lopez ML, Gomez RA, Smithies O, Kim HS (2005) Homeostatic responses in the adrenal cortex to the absence of aldosterone in mice. Endocrinology 146:2650-2656

72. Lenzini L, Caroccia B, Campos AG, Fassina A, Belloni AS, Seccia TM, Kuppusamy M, Ferraro S, Skander G, Bader M, Rainey WE et al (2014) Lower expression of the TWIK-related acid-sensitive $\mathrm{K}+$ channel 2 (TASK-2) gene is a hallmark of aldosteroneproducing adenoma causing human primary aldosteronism. J Clin Endocrinol Metab 99:E674-E682

73. Liang B, Soka M, Christensen AH, Olesen MS, Larsen AP, Knop FK, Wang F, Nielsen JB, Andersen MN, Humphreys D, Mann SA et al (2014) Genetic variation in the two-pore domain potassium channel, TASK-1, may contribute to an atrial substrate for arrhythmogenesis. J Mol Cell Cardiol 67:69-76
74. Liao Y, Plummer NW, George MD, Abramowitz J, Zhu MX, Birnbaumer L (2009) A role for Orai in TRPC-mediated Ca2+ entry suggests that a TRPC: Orai complex may mediate store and receptor operated Ca2+ entry. Proc Natl Acad Sci U S A 106:3202-3206

75. Lifton RP, Dluhy RG, Powers M, Rich GM, Gutkin M, Fallo F, Gill JR Jr, Feld L, Ganguly A, Laidlaw JC (1992) Hereditary hypertension caused by chimaeric gene duplications and ectopic expression of aldosterone synthase. Nat Genet 2:66-74

76. Lin D, Sugawara T, Strauss JF III, Clark BJ, Stocco DM, Saenger P, Rogol A, Miller WL (1995) Role of steroidogenic acute regulatory protein in adrenal and gonadal steroidogenesis. Science 267:18281831

77. Linden AM, Aller MI, Leppa E, Rosenberg PH, Wisden W, Korpi ER (2008) $\mathrm{K}+$ channel TASK-1 knockout mice show enhanced sensitivities to ataxic and hypnotic effects of GABA(A) receptor ligands. J Pharmacol Exp Ther 327:277-286

78. Linden AM, Aller MI, Leppa E, Vekovischeva O, Aitta-Aho T, Veale EL, Mathie A, Rosenberg P, Wisden W, Korpi ER (2006) The in vivo contributions of TASK-1-containing channels to the actions of inhalation anesthetics, the alpha(2) adrenergic sedative dexmedetomidine, and cannabinoid agonists. J Pharmacol Exp Ther 317:615-626

79. Lindner M, Leitner MG, Halaszovich CR, Hammond GR, Oliver D (2011) Probing the regulation of TASK potassium channels by PI4, $5 \mathrm{P}(2)$ with switchable phosphoinositide phosphatases. J Physiol 589:3149-3162

80. Liu H, Enyeart JA, Enyeart JJ (2007) Angiotensin II inhibits native bTREK-1 K+ channels through a PLC-, kinase C-, and PIP2independent pathway requiring ATP hydrolysis. Am J Physiol Cell Physiol 293:C682-C695

81. Liu H, Enyeart JA, Enyeart JJ (2008) ACTH inhibits bTREK-1 K+ channels through multiple cAMP-dependent signaling pathways. J Gen Physiol 132:279-294

82. Liu H, Enyeart JA and Enyeart JJ (2009) N6-substituted cAMP Analogs Inhibit bTREK-1 K+ channels and stimulate cortisol secretion by a PKA-Independent mechanism. Mol Pharmacol

83. Lotshaw DP (2006) Biophysical and pharmacological characteristics of native two-pore domain TASK channels in rat adrenal glomerulosa cells. J Membr Biol 210:51-70

84. Lu HK, Fern RJ, Luthin D, Linden J, Liu LP, Cohen CJ, Barrett PQ (1996) Angiotensin II stimulates T-type Ca2+ channel currents via activation of a G protein, Gi. Am J Physiol 271:C1340-C1349

85. Ma L, Roman-Campos D, Austin ED, Eyries M, Sampson KS, Soubrier F, Germain M, Tregouet DA, Borczuk A, Rosenzweig EB, Girerd B et al (2013) A novel channelopathy in pulmonary arterial hypertension. N Engl J Med 369:351-361

86. Ma L, Zhang X, Zhou M, Chen H (2012) Acid-sensitive TWIK and TASK two-pore domain potassium channels change ion selectivity and become permeable to sodium in extracellular acidification. $\mathrm{J}$ Biol Chem 287:37145-37153

87. Mathie A (2007) Neuronal two-pore-domain potassium channels and their regulation by G protein-coupled receptors. J Physiol 578:377385

88. McEwan PE, Vinson GP, Kenyon CJ (1999) Control of adrenal cell proliferation by AT1 receptors in response to angiotensin II and lowsodium diet. Am J Physiol 276:E303-E309

89. Meimaridou E, Kowalczyk J, Guasti L, Hughes CR, Wagner F, Frommolt P, Nurnberg P, Mann NP, Banerjee R, Saka HN, Chapple JP et al (2012) Mutations in NNT encoding nicotinamide nucleotide transhydrogenase cause familial glucocorticoid deficiency. Nat Genet 44:740-742

90. Meuth SG, Aller MI, Munsch T, Schuhmacher T, Seidenbecher T, Meuth P, Kleinschnitz C, Pape HC, Wiendl H, Wisden W, Budde T (2006) The contribution of TWIK-related acid-sensitive K+-containing channels to the function of dorsal lateral geniculate thalamocortical relay neurons. Mol Pharmacol 69:1468-1476 
91. Mirkovic K, Palmersheim J, Lesage F, Wickman K (2012) Behavioral characterization of mice lacking Trek channels. Front Behav Neurosci 6:60

92. Monticone S, Hattangady NG, Penton D, Isales C, Edwards MA, Williams TA, Sterner C, Warth R, Mulatero P and Rainey WE (2013) A novel Y152C KCNJ5 mutation responsible for familial hyperaldosteronism type III. J Clin Endocrinol Metab Epub ahead of print:

93. Murthy M, Azizan EA, Brown MJ, O'Shaughnessy KM (2012) Characterization of a novel somatic KCNJ5 mutation delI157 in an aldosterone-producing adenoma. J Hypertens 30:1827-1833

94. Natke E Jr, Kabela E (1979) Electrical responses in cat adrenal cortex: possible relation to aldosterone secretion. Am J Physiol 237:E158-E162

95. Nishi H, Arai H, Momiyama T (2013) NCI-H295R, a human adrenal cortex-derived cell line, expresses purinergic receptors linked to $\mathrm{Ca}(2)(+)$-mobilization/influx and cortisol secretion. PLoS One 8:e71022

96. Nogueira EF, Gerry D, Mantero F, Mariniello B, Rainey WE (2010) The role of TASK1 in aldosterone production and its expression in normal adrenal and aldosterone-producing adenomas. Clin Endocrinol (Oxf) 73:22-29

97. Nussberger J (2003) Investigating mineralocorticoid hypertension. J Hypertens Suppl 21:S25-S30

98. Oki K, Plonczynski MW, Lam ML, Gomez-Sanchez EP, GomezSanchez CE (2012) The potassium channel, Kir3.4 participates in angiotensin II-stimulated aldosterone production by a human adrenocortical cell line. Endocrinology 153:4328-4335

99. Oki K, Plonczynski MW, Luis LM, Gomez-Sanchez EP, GomezSanchez CE (2012) Potassium channel mutant KCNJ5 T158A expression in HAC-15 cells increases aldosterone synthesis. Endocrinology 153:1774-1782

100. Otis M, Gallo-Payet N (2007) Role of MAPKs in angiotensin IIinduced steroidogenesis in rat glomerulosa cells. Mol Cell Endocrinol 265-266:126-130

101. Paul M, Poyan MA, Kreutz R (2006) Physiology of local reninangiotensin systems. Physiol Rev 86:747-803

102. Payet MD, Durroux T, Bilodeau L, Guillon G, Gallo-Payet N (1994) Characterization of $\mathrm{K}+$ and $\mathrm{Ca} 2+$ ionic currents in glomerulosa cells from human adrenal glands. Endocrinology 134:2589-2598

103. Penton D, Bandulik S, Schweda F, Haubs S, Tauber P, Reichold M, Cong LD, El WA, Budde T, Lesage F, Lalli E et al (2012) Task3 potassium channel gene invalidation causes low renin and saltsensitive arterial hypertension. Endocrinology 153:4740-4748

104. Peters J (2012) Local renin-angiotensin systems in the adrenal gland. Peptides 34:427-432

105. Peters J, Obermuller N, Woyth A, Peters B, Maser-Gluth C, Kranzlin B, Gretz N (1999) Losartan and angiotensin II inhibit aldosterone production in anephric rats via different actions on the intraadrenal renin-angiotensin system. Endocrinology 140: 675-682

106. Philipp S, Trost C, Warnat J, Rautmann J, Himmerkus N, Schroth G, Kretz O, Nastainczyk W, Cavalie A, Hoth M, Flockerzi V (2000) TRP4 (CCE1) protein is part of native calcium release-activated $\mathrm{Ca} 2+$-like channels in adrenal cells. J Biol Chem 275:23965-23972

107. Pralong WF, Hunyady L, Varnai P, Wollheim CB, Spat A (1992) Pyridine nucleotide redox state parallels production of aldosterone in potassium-stimulated adrenal glomerulosa cells. Proc Natl Acad Sci U S A 89:132-136

108. Quinn SJ, Cornwall MC, Williams GH (1987) Electrical properties of isolated rat adrenal glomerulosa and fasciculata cells. Endocrinology 120:903-914

109. Quinn SJ, Williams GH, Tillotson DL (1988) Calcium oscillations in single adrenal glomerulosa cells stimulated by angiotensin II. Proc Natl Acad Sci U S A 85:5754-5758
110. Radke KJ, Schneider EG, Taylor RE Jr, Kramer RE (1986) Effect of hydrogen ion concentration on corticosteroid secretion. Am J Physiol 250:E259-E264

111. Remuzzi G, Perico N, Macia M and Ruggenenti P (2005) The role of renin-angiotensin-aldosterone system in the progression of chronic kidney disease. Kidney Int SupplS57-S65

112. Rohacs T, Bago A, Deak F, Hunyady L, Spat A (1994) Capacitative $\mathrm{Ca} 2+$ influx in adrenal glomerulosa cells: possible role in angiotensin II response. Am J Physiol 267:C1246-C1252

113. Rohacs T, Nagy G, Spat A (1997) Cytoplasmic Ca2+ signalling and reduction of mitochondrial pyridine nucleotides in adrenal glomerulosa cells in response to $\mathrm{K}+$, angiotensin II and vasopressin. Biochem J 322(Pt 3):785-792

114. Romero DG, Yanes LL, de Rodriguez AF, Plonczynski MW, Welsh BL, Reckelhoff JF, Gomez-Sanchez EP, Gomez-Sanchez CE (2007) Disabled-2 is expressed in adrenal zona glomerulosa and is involved in aldosterone secretion. Endocrinology 148:2644-2652

115. Rossig L, Zolyomi A, Catt KJ, Balla T (1996) Regulation of angiotensin II-stimulated $\mathrm{Ca} 2+$ oscillations by $\mathrm{Ca} 2+$ influx mechanisms in adrenal glomerulosa cells. J Biol Chem 271: 22063-22069

116. Sarzani R, Pietrucci F, Francioni M, Salvi F, Letizia C, D'Erasmo E, Dessi FP, Rappelli A (2006) Expression of potassium channel isoforms mRNA in normal human adrenals and aldosteronesecreting adenomas. J Endocrinol Invest 29:147-153

117. Sato Y, Maekawa S, Ishii R, Sanada M, Morikawa T, Shiraishi Y, Yoshida K, Nagata Y, Sato-Otsubo A, Yoshizato T, Suzuki H et al (2014) Recurrent somatic mutations underlie corticotropinindependent Cushing's syndrome. Science 344:917-920

118. Sausbier M, Arntz C, Bucurenciu I, Zhao H, Zhou XB, Sausbier U, Feil S, Kamm S, Essin K, Sailer CA, Abdullah U et al (2005) Elevated blood pressure linked to primary hyperaldosteronism and impaired vasodilation in BK channel-deficient mice. Circulation 112:60-68

119. Scandling JD, Ornt DB (1987) Mechanism of potassium depletion during chronic metabolic acidosis in the rat. Am J Physiol 252: F122-F130

120. Schambelan M, Sebastian A, Katuna BA, Arteaga E (1987) Adrenocortical hormone secretory response to chronic $\mathrm{NH} 4 \mathrm{Cl}$ induced metabolic acidosis. Am J Physiol 252:E454-E460

121. Schiekel J, Lindner M, Hetzel A, Wemhoner K, Renigunta V, Schlichthorl G, Decher N, Oliver D, Daut J (2013) The inhibition of the potassium channel TASK-1 in rat cardiac muscle by endothelin-1 is mediated by phospholipase C. Cardiovasc Res 97: 97-105

122. Scholl UI, Lifton RP (2013) New insights into aldosteroneproducing adenomas and hereditary aldosteronism: mutations in the $\mathrm{K}+$ channel KCNJ5. Curr Opin Nephrol Hypertens 22: 141-147

123. Scholl UI, Nelson-Williams C, Yue P, Grekin R, Wyatt RJ, Dillon MJ, Couch R, Hammer LK, Harley FL, Farhi A, Wang WH et al (2012) Hypertension with or without adrenal hyperplasia due to different inherited mutations in the potassium channel KCNJ5. Proc Natl Acad Sci U S A 109:2533-2538

124. Sculptoreanu A, Scheuer T, Catterall WA (1993) Voltagedependent potentiation of L-type $\mathrm{Ca} 2+$ channels due to phosphorylation by cAMP-dependent protein kinase. Nature 364: 240-243

125. Sewer MB, Waterman MR (2003) ACTH modulation of transcription factors responsible for steroid hydroxylase gene expression in the adrenal cortex. Microsc Res Tech 61:300-307

126. Silver S (1940) The Cushing syndrome; neoplasms of the adrenal gland. Bull N Y Acad Med 16:368-380

127. Simpson ER, Waterman MR (1988) Regulation of the synthesis of steroidogenic enzymes in adrenal cortical cells by ACTH. Annu Rev Physiol 50:427-440 
128. Spat A, Fulop L, Szanda G (2012) The role of mitochondrial Ca(2+) and $\mathrm{NAD}(\mathrm{P}) \mathrm{H}$ in the control of aldosterone secretion. Cell Calcium 52:64-72

129. Spat A, Hunyady L (2004) Control of aldosterone secretion: a model for convergence in cellular signaling pathways. Physiol Rev 84:489-539

130. Spyroglou A, Manolopoulou J, Wagner S, Bidlingmaier M, Reincke M, Beuschlein F (2009) Short term regulation of aldosterone secretion after stimulation and suppression experiments in mice. $\mathrm{J}$ Mol Endocrinol 42:407-413

131. Stachowiak A, Nussdorfer GG, Malendowicz LK (1990) Proliferation and distribution of adrenocortical cells in the gland of ACTH- or dexamethasone-treated rats. Histol Histopathol 5:25-29

132. Suwa T, Chen M, Hawks CL, Hornsby PJ (2003) Zonal expression of dickkopf-3 and components of the Wnt signalling pathways in the human adrenal cortex. J Endocrinol 178:149-158

133. Tauber P, Penton D, Stindl J, Humberg E, Tegtmeier I, Sterner C, Beuschlein F, Reincke M, Barhanin J, Bandulik S, Warth R (2014) Pharmacology and pathophysiology of mutated KCNJ5 found in adrenal aldosterone-producing adenomas. Endocrinology 155: 1353-1362

134. Thomas M, Keramidas M, Monchaux E, Feige JJ (2004) Dual hormonal regulation of endocrine tissue mass and vasculature by adrenocorticotropin in the adrenal cortex. Endocrinology 145: 4320-4329

135. Trapp S, Aller MI, Wisden W, Gourine AV (2008) A role for TASK1 (KCNK3) channels in the chemosensory control of breathing. J Neurosci 28:8844-8850

136. Tremblay E, Payet MD, Gallo-Payet N (1991) Effects of ACTH and angiotensin II on cytosolic calcium in cultured adrenal glomerulosa cells. Role of cAMP production in the ACTH effect. Cell Calcium 12:655-673

137. Uebele VN, Nuss CE, Renger JJ, Connolly TM (2004) Role of voltage-gated calcium channels in potassium-stimulated aldosterone secretion from rat adrenal zona glomerulosa cells. J Steroid Biochem Mol Biol 92:209-218

138. Vallon V, Grahammer F, Volkl H, Sandu CD, Richter K, Rexhepaj R, Gerlach U, Rong Q, Pfeifer K, Lang F (2005) KCNQ1- dependent transport in renal and gastrointestinal epithelia. Proc Natl Acad Sci U S A 102:17864-17869

139. Varnai P, Hunyady L, Balla T (2009) STIM and Orai: the longawaited constituents of store-operated calcium entry. Trends Pharmacol Sci 30:118-128

140. Veale EL, Hassan M, Walsh Y, Al-Moubarak E, Mathie A (2014) Recovery of current through mutated TASK3 potassium channels underlying Birk Barel syndrome. Mol Pharmacol 85:397-407

141. Wang Y, Yamaguchi T, Franco-Saenz R, Mulrow PJ (1992) Regulation of renin gene expression in rat adrenal zona glomerulosa cells. Hypertension 20:776-781

142. Westphalen RI, Krivitski M, Amarosa A, Guy N, Hemmings HC Jr (2007) Reduced inhibition of cortical glutamate and GABA release by halothane in mice lacking the $\mathrm{K}+$ channel, TREK-1. Br J Pharmacol 152:939-945

143. White RE, Lee AB, Shcherbatko AD, Lincoln TM, Schonbrunn A, Armstrong DL (1993) Potassium channel stimulation by natriuretic peptides through cGMP-dependent dephosphorylation. Nature 361: 263-266

144. Wiederkehr A, Szanda G, Akhmedov D, Mataki C, Heizmann CW, Schoonjans K, Pozzan T, Spat A, Wollheim CB (2011) Mitochondrial matrix calcium is an activating signal for hormone secretion. Cell Metab 13:601-611

145. Wilke BU, Lindner M, Greifenberg L, Albus A, Leitner MG, Oliver D (2014) TASK1/3 inhibition by Gq-protein coupled receptors is mediated by diacylglycerol. Acta Physiol 210:8181, Abstract

146. Williams DLJ, Katz GM, Roy-Contancin L, Reuben JP (1988) Guanosine 5'-monophosphate modulates gating of highconductance $\mathrm{Ca} 2+$-activated $\mathrm{K}+$ channels in vascular smooth muscle cells. Proc Natl Acad Sci U S A 85:9360-9364

147. Xu H, Garver H, Galligan JJ, Fink GD (2011) Largeconductance $\mathrm{Ca} 2+$-activated $\mathrm{K}+$ channel beta1-subunit knockout mice are not hypertensive. Am J Physiol Heart Circ Physiol 300:H476-H485

148. Young MJ, Rickard AJ (2012) Mechanisms of mineralocorticoid salt-induced hypertension and cardiac fibrosis. Mol Cell Endocrinol 350:248-255 